\title{
Effects of Natural Compounds on Microbial Safety and Sensory Quality of Fior di Latte Cheese, a Typical Italian Cheese
}

\author{
D. Gammariello, ${ }^{*}$ S. Di Giulio, $\dagger$ A. Conte,,+ and M. A. Del Nobile ${ }^{*} \dagger^{1}$ \\ *Istituto per la Ricerca e le Applicazioni Biotecnologiche per la Sicurezza e la Valorizzazione dei Prodotti Tipici e di Qualità, Università degli Studi \\ di Foggia, Via Napoli, 25-71100 Foggia, Italia \\ †Dipartimento di Scienze degli Alimenti, Università di Foggia, Via Napoli, 25-71100 Foggia, Italia
}

\begin{abstract}
This work presents a preliminary study to assess the efficiency of plant essential oils as natural food preservatives in Fior di Latte cheese. Selected compounds were directly dissolved into Fior di Latte brine. Packaged Fior di Latte samples were stored at $10^{\circ} \mathrm{C}$ for about 6 $\mathrm{d}$. The cell loads of spoilage and useful microorganisms were monitored to calculate the microbial acceptability limit. Results show that some tested compounds were not acceptable by the panel from a sensorial point of view. Most compounds did not affect the microbial acceptability limit value to a great extent, and only a few such as lemon, sage, and thyme markedly prolonged the microbial acceptability limit of the investigated fresh cheese. Moreover, the above active agents exerted an inhibitory effect on the microorganisms responsible for spoilage without affecting the dairy microflora.
\end{abstract}

Key words: antimicrobial compound, Fior di Latte cheese, microbial safety, shelf life

\section{INTRODUCTION}

Fior di Latte is an unripened "pasta filata" cheese made from cow's milk, and is similar to Mozzarella cheese, a typical dairy product of Southern Italy. The name "Fior di Latte" is used to distinguish the Mozzarella made from cow's milk from that made from buffalo's milk. The manufacture of this cheese has been described in detail in the literature (Parente and Moschetti, 1997; Salvadori del Prato, 2001). It is manufactured according to traditional procedures (raw milk inoculated with natural whey or milk cultures, raw milk ripened under special conditions, without starter addition) or by using pasteurized milk and commercial starter cultures of lactic acid bacteria (Salvadori del Prato, 2001). Although Mozzarella cheese receives heat treatment during curd stretching, post-processing

Received March 4, 2008.

Accepted July 4, 2008.

${ }^{1}$ Corresponding author: ma.delnobile@unifg.it contamination by microorganisms may occur, causing cheese spoilage, health risks for consumers, and reduction in shelf life (Spano et al., 2003). Few reports are available on methods to prolong the shelf life of fresh cheese. In fact, the main factories use liquid (diluted whey or water from the stretcher-molder) to preserve Fior di Latte cheese. During storage, mass transfer between the product and the liquid occurs and this phenomenon is strictly linked to the composition, microbial growth, moisture degree, liquid type, and storage conditions (Mucchetti and Neviani, 2006).

The application of antimicrobial agents to Fior di Latte packaging could be useful to prevent the growth of spoilage microorganisms and hence, may lead to an extension of shelf life and improved microbial safety of this product. Dairy researchers (Smith-Palmer et al., 2001; Conte et al., 2007a) have found that selected plant essential oils can act as inhibitors of spoilage microorganisms in food products.

The antimicrobial properties of plant essential oils are well known against a wide spectrum of microbes, including bacteria (Deans and Ritchie, 1987; LisBalchin and Deans, 1997; Smith-Palmer et al., 1998), yeasts (Lachowicz et al., 1998; Mangena and Muyima, 1999), and fungi (Paster et al., 1990; Mishra and Dubey, 1994). Many scientific reports highlight the antimicrobial effects of these substances by in vitro test (Delaquis et al., 2002). Some researchers (Nakatani, 1994; Marino et al., 2001) reported that gram-positive bacteria are more sensitive to essential oils than gramnegative bacteria, but others (Kim et al., 1995; Skandamis et al., 2002) did not observe differences related to this characteristic. The ability of natural compounds to differently inhibit gram-positive or negative bacteria is of considerable importance in the food industry. It has generally been found that a greater concentration of essential oils is needed to achieve the same effect in foods, compared with antibacterial assays in vitro (Shelef, 1983; Smid and Gorris, 1999). The great availability of nutrients in foods compared with laboratory media may enable bacteria to repair damaged cells (Gill et al., 2002). Both the intrinsic (fat, protein, water 
Table 1. Microbial acceptability limit $(\mathrm{MAL} ; \pm \mathrm{SD})$ values related to Pseudomonas spp. $\left(\mathrm{MAL}_{\mathrm{P}}\right)$ and coliforms $\left(\mathrm{MAL}_{\mathrm{C}}\right)$

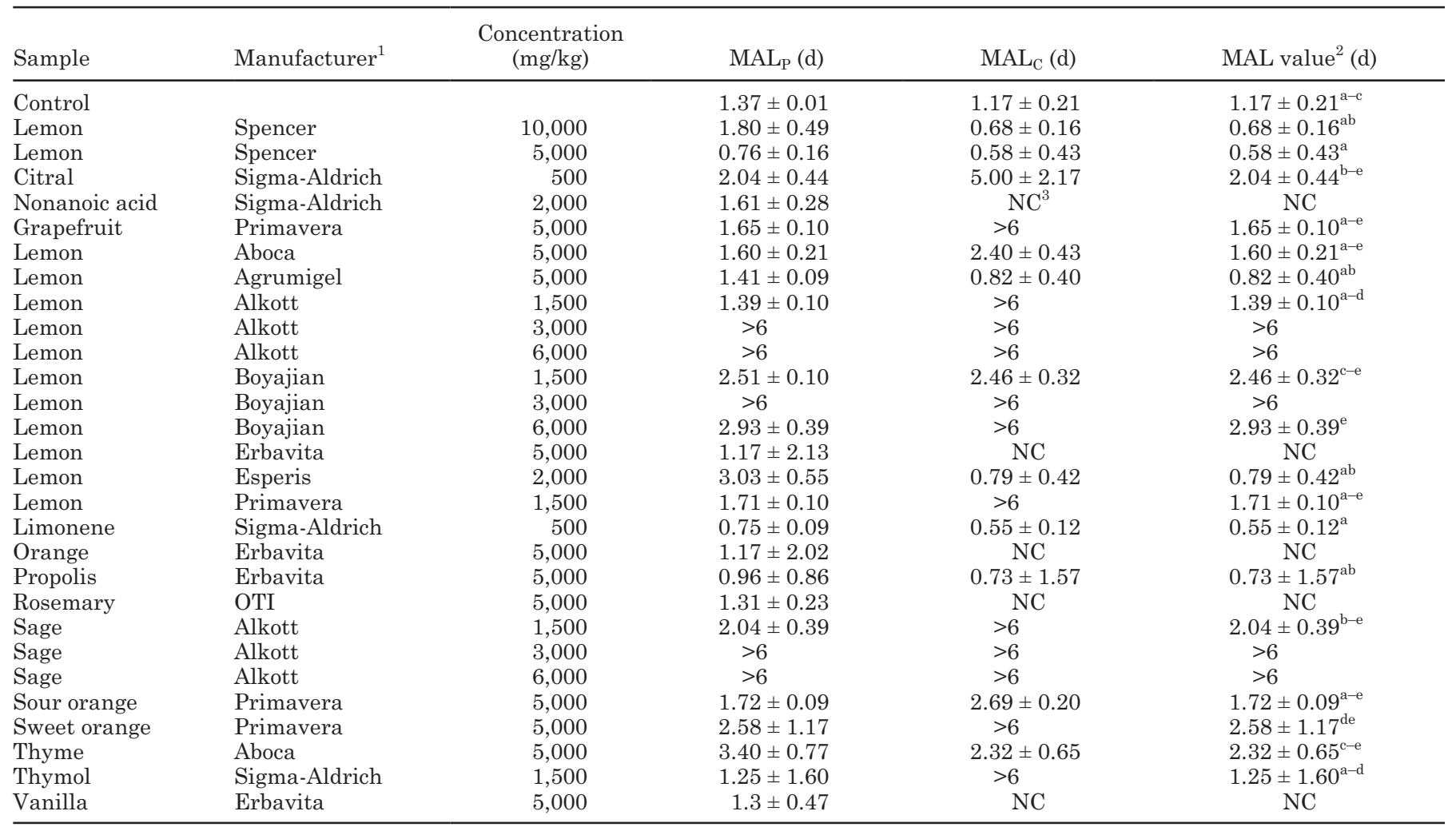

${ }^{\mathrm{a}-\mathrm{e}}$ Means within the column with different superscript letters are significantly different $(P<0.05)$.

${ }^{1}$ Spencer (Amsterdam, the Netherlands); Sigma-Aldrich (Milan, Italy); Primavera (Lorenzana, Italy); Aboca (Arezzo, Italy); Agrumigel (Pozzo di Gotto, Italy); Alkott (Milan, Italy); Boyajian (Canton, MA); Erbavita (Chiesanuova, Italy); Esperis (Milan, Italy); OTI (Domegge di Cadore, Italy).

${ }^{2}$ The lowest MAL value among those calculated for each spoilage microrganism was reported.

${ }^{3} \mathrm{NC}=$ not calculated.

content, antioxidants, $\mathrm{pH}$, salt, and other additives) and the extrinsic properties (temperature, packaging in vacuum/gas/air, characteristics of microorganisms) of the food can influence bacterial sensitivity to natural extracts from plants (Shelef, 1983; Tassau et al., 2000).

Because of the potential use of active natural compounds for food preservation and the lack of research on active packaging systems applied to fresh dairy products, we evaluated the effects of different natural compounds on standard hygienic quality of Fior di Latte cheese during storage at $10^{\circ} \mathrm{C}$.

\section{MATERIALS AND METHODS}

\section{Active Compounds and Media}

Salvia officinalis and Citrus limonum were purchased from Alkott (Milan, Italy), Thymus vulgaris from Aboca (Arezzo, Italy), Rosmarinus officinalis from OTI (Domegge di Cadore, Italy), Citrus aurantium, Cit- rus sinensis, and Citrus paradisii macf from Primavera (Lorenzana, Italy). Moreover, different essential oils from Citrus limonum were purchased from Agrumigel (Barcellona, Pozzo di Gotto, Italy), Esperis (Milan, Italy), Aboca, Erbavita (Chiesanuova, Italy), Primavera, Boyajian (Canton, MA), and Spencer (Amsterdam, the Netherlands). Finally, the hydroalcoholic extracts Melaleuca alternifolia, Mentha piperita, Propolis, and Vanilla planifolia were purchased from Erbavita and citral 95\%, nonanoic acid 96\%, thymol, and limonene from Sigma-Aldrich (Milan, Italy). The concentrations of the selected active compounds are listed in Table 1. All media used for microbiological analyses were purchased from Oxoid (Milan, Italy).

\section{Sensory Evaluation}

The solutions used for sensorial testing were prepared by diluting each natural compound at different concentrations in brine solutions. All active solutions were prepared $24 \mathrm{~h}$ before sensory panel evaluation and 
were held at $10^{\circ} \mathrm{C}$ in an odor-free environment. Samples were equilibrated to room temperature immediately before testing. Sensory evaluation was carried out by 5 panelists, members of the Food Packaging Laboratory of the University of Foggia. They were selected based on their interest in the sensory evaluation of dairy products. Coded portions of each sample $(20 \mathrm{~mL})$ were presented to the panelists in random order. The natural extracts were evaluated for odor acceptability using a 5-point scale: $0=$ not perceptible, $1=$ barely perceptible, $2=$ low intensity, $3=$ medium intensity, 4 $=$ great intensity, and $5=$ extreme intensity. Panelists were also asked to score the defects of the active solution on a panel scale to determine the reasons for the decrease in scores for the discriminated off-odors.

\section{Fior di Latte Cheese Production and Packaging}

The Fior di Latte cheese used in this work was manufactured in the Posta la Via dairy plant (Foggia, Italy), according to the following procedure: raw cow's milk was acidified with lactic acid and liquid rennet was added. Curd formation was achieved after approximately 15 to $20 \mathrm{~min}$. When the curd $\mathrm{pH}$ reached a value of about 5.80, the whey was removed; the curd was cut, stretched, and molded. The application of heat $\left(82^{\circ} \mathrm{C}\right)$ to cheese curd during the manufacturing of Mozzarella is to selectively control the growth of certain types of bacteria and, consequently, to influence the maturation pathway of the cheese. After tempering in cold water, samples of about $50 \mathrm{~g}$ were packaged in polypropylene tubs using either brine or active brine. Brine consisted of $2 \% \mathrm{NaCl}$ solution, whereas active brine was obtained by dissolving each antimicrobial compound at different concentrations into salt solution. The samples were stored at $10^{\circ} \mathrm{C}$ for $6 \mathrm{~d}$.

\section{Microbiological Analyses}

Microbiological analyses were performed before packaging and after 1, 2, 5, and $6 \mathrm{~d}$ of storage. Twenty grams of Fior di Latte cheese was diluted in $180 \mathrm{~mL}$ of Ringer's solution and homogenized in a blender (Stomacher, International PBI, Milan, Italy). Subsequent serial dilutions were made in Ringer's solution and plated in the following media: plate count agar, incubated at $30^{\circ} \mathrm{C}$ for $48 \mathrm{~h}$ for total mesophilic bacteria; de Man, Rogosa, and Sharpe (MRS) agar, supplemented with cycloheximide (100 mg/L, Sigma), incubated under anaerobiosis (Anaerogen Gas Pack, Oxoid) at $37^{\circ} \mathrm{C}$ for $48 \mathrm{~h}$ for lactic acid bacilli; M17 agar, incubated at $37^{\circ} \mathrm{C}$ for $48 \mathrm{~h}$ for lactococci; yeast peptone dextrose agar, supplemented with chloramphenicol $(0.1 \mathrm{~g} / \mathrm{L})$ incubated at $30^{\circ} \mathrm{C}$ for $48 \mathrm{~h}$ for yeasts and molds; violet red bile lactose agar incubated at $37^{\circ} \mathrm{C}$ for $24 \mathrm{~h}$ for total coliforms; pseudomonas agar base, with SR103 E selective supplement (Oxoid), incubated at $25^{\circ} \mathrm{C}$ for $48 \mathrm{~h}$ for Pseudomonas spp.

\section{pH Determination}

Determination of $\mathrm{pH}$ was performed at the same sampling time of the microbiological analyses by using a pH meter (Crison 2001, Crison, Barcelona, Spain). Measures were carried out on both liquid and cheese samples.

\section{Calculation of Microbial Acceptability Limit}

The microbial acceptability limit (MAL) values of each spoilage microorganism were obtained by fitting the Gompertz equation as reparameterized by Corbo et al. (2006) to the growth cycle data:

$$
\begin{gathered}
\log (N(t))=\log \left(N_{\max }\right)- \\
A \cdot \exp \left\{-\exp \left\{\left[\left(\mu_{\max } \cdot 2.71\right) \cdot \frac{\lambda-M A L}{A}\right]+1\right\}\right\}+ \\
A \cdot \exp \left\{-\exp \left\{\left[\left(\mu_{\max } \cdot 2.71\right) \cdot \frac{\lambda-t}{A}\right]+1\right\}\right\},
\end{gathered}
$$

where $N(t)$ is the viable cell concentration (cfu/g) at time $t, A$ is related to the difference between the decimal logarithm of maximum bacteria growth attained at the stationary phase and the decimal logarithm of the initial value of viable cell concentration, $\mu_{\max }$ is the maximal specific growth rate $(\Delta \log [\mathrm{cfu} / \mathrm{g}] / \mathrm{d}), \lambda$ is the lag time (d) and $t$ is the time (d), $N_{\max }$ is the microbial threshold limit (cfu/g), and MAL is the time at which the microbiological threshold limit is reached [d; i.e., the time at which $N(t)$ is equal to $N_{\max }$ ].

\section{Statistical Analyses}

The MAL values were compared by one-way ANOVA. A Duncan's multiple range test with the option of homogeneous groups $(P<0.05)$ was used to determine significance between treatments. Statistica 7.1 for Windows (Stat-Soft Inc., Tulsa, OK) was used for this purpose.

\section{RESULTS AND DISCUSSION}

The effectiveness of different antimicrobial agents on the microbial quality decay of Fior di Latte cheese during storage at $10^{\circ} \mathrm{C}$ is addressed. Microbial quality 
was assessed by monitoring the growth cycle of both Pseudomonas spp. and coliforms as representative spoilage microorganisms of the selected dairy product. To assess the effect of different natural compounds on typical microflora, the viable cell concentration of lactic acid bacteria was also monitored. Results on each microbial group are reported separately in the following.

\section{Selection of Natural Compounds}

The concentrations of several natural compounds used in this work ranged from 500 to $10,000 \mathrm{mg} / \mathrm{kg}$. This wide range was chosen to guarantee a significant antimicrobial effect. In fact, according to data reported in the literature, these concentrations should range from 0.5 to $1 \%$ (Vrinda Menon and Garg, 2001). Moreover, it was also taken into account that the concentration of oil in food should be greater than in laboratory media to achieve the same antimicrobial efficiency because of the complex nature of food (Holley and Patel, 2005).

Several essential oils were screened by a panel test for suitability for dairy applications. Among the selected natural compounds, the panelists selected the following: Salvia officinalis (sage), Thymus vulgaris (thyme), Rosmarinus officinalis (rosemary), Citrus aurantium (sour orange), Citrus sinensis (sweet orange), Citrus paradisii macf (grapefruit), Citrus limonum (lemon essential oil), Propolis, Vanilla planifoli (vanilla), and hydroalcoholic extracts such as citral 95\%, thymol, and nonanoic acid 96\%. Natural compounds such as Melaleuca alternifolia (melaleuca) and Mentha piperita (mint) were discarded because the panelists disliked their smell when applied to dairy products. In addition, greater concentrations of natural compounds such as sage, thyme, rosemary, grapefruit, vanilla, and sour or sweet orange dissolved in salt solutions were found acceptable because they were below the threshold of perception.

\section{Pseudomonas Species}

Figures 1, 2, and 3 illustrate the evolution of Pseudomonas spp. counts plotted as a function of the storage period for the investigated compounds. Data related to the control sample (packaged in brine) shows this trend: a short lag phase, followed by an increase in the viable cell concentration until the stationary phase. Because of the high number of natural compounds, these have been divided into 3 groups based on antimicrobial effect: high, medium, or low. To quantitatively determine the effectiveness of the tested compounds in inhibiting the Pseudomonas spp. growth cycle, equation [1] was fitted to the experimental data. The fitting procedure allowed us to determine the MAL values re-

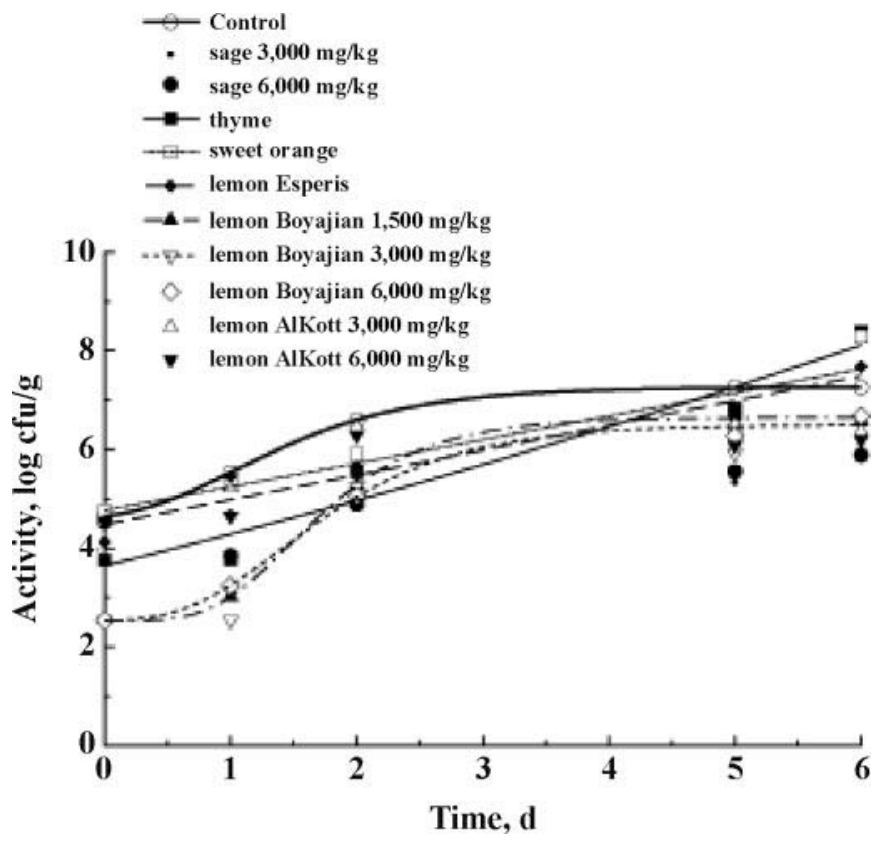

Figure 1. Antimicrobial activity of highly effective compounds on Pseudomonas spp. count in Fior di latte cheese during storage at $10^{\circ} \mathrm{C}$. The curves shown in the figure are the best fit of the reparameterized Gompertz equation to the experimental data.

lated to Pseudomonas $\left(\mathbf{M A L}_{\mathbf{P}}\right)$ for each natural preservative tested in this investigation (Table 1 ). The value of $\log \left(N_{\max }\right)$ was set to 6 because at this level of contamination with Pseudomonas spp., alterations in the product begin to appear (Bishop and White, 1986). As we can see in Figure 1, sage and lemon (Boyajian and Alkott) do not reach a microbial level $\left(10^{6} \mathrm{cfu} / \mathrm{g}\right)$, enabling us to consider the MAL to be $>6 \mathrm{~d}$ (Table 1 ). The other substances caused the evolution of Pseudomonas spp. count to decrease dramatically during the observation period. Conte et al. (2007a) have also shown that lemon may exert an inhibitory effect on the growth of spoilage microorganisms in Mozzarella cheese. In addition, literature data recorded on different food matrices confirm the pronounced antimicrobial effect of citrus essential oils (Tassou et al., 1996; Caccioni et al., 1998; Dorman and Deans, 2000; Lanciotti et al., 2004).

Figure 2 shows a slight decrease in cell concentration with compounds such as sage (Alkott) at $1,500 \mathrm{mg} / \mathrm{kg}$, lemon $20 \%$ (Spencer) at 10,000 mg/kg, lemon (Primavera) at $1,500 \mathrm{mg} / \mathrm{kg}$, lemon (Erbavita) at $5,000 \mathrm{mg} / \mathrm{kg}$, orange, citral, sour orange, and thymol. The values of MAL $_{P}$ (Table 1) are similar to those of the control.

Natural compounds such as rosemary, lemon $20 \%$ (Spencer) at $5,000 \mathrm{mg} / \mathrm{kg}$, propolis, limonene, lemon (Agrumigel) at $5,000 \mathrm{mg} / \mathrm{kg}$, vanilla, lemon (Alkott) at $1,500 \mathrm{mg} / \mathrm{kg}$, grapefruit, lemon (Aboca), and nonanoic acid do not greatly change the Pseudomonas spp. 


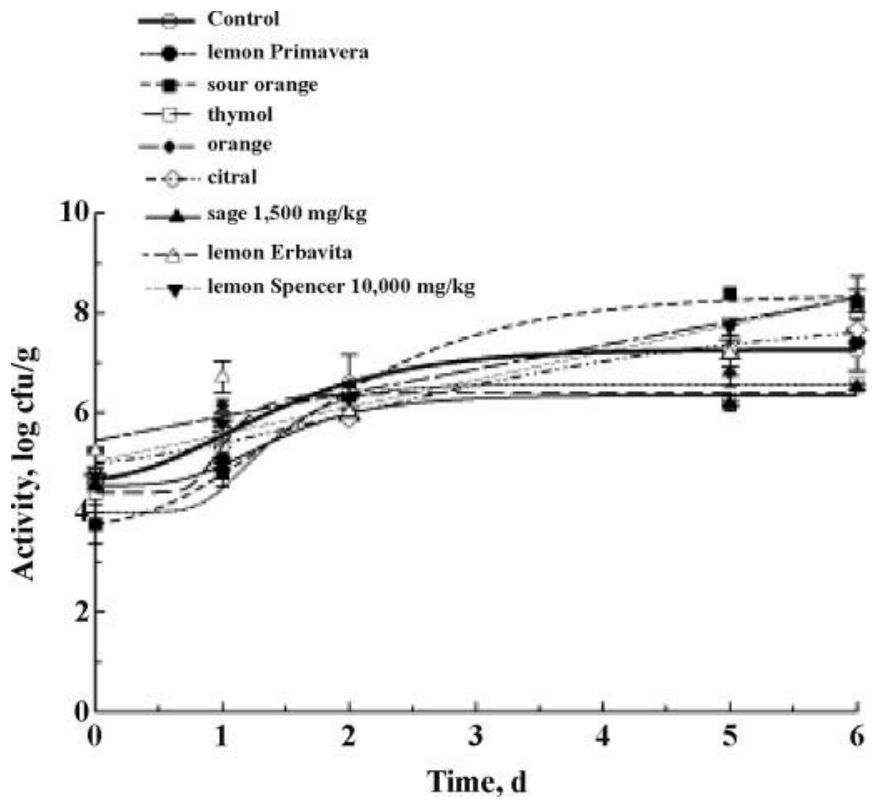

Figure 2. Antimicrobial activity of slowly effective compounds on Pseudomonas spp. count in Fior di latte cheese during storage at $10^{\circ} \mathrm{C}$. The curves shown in the figure are the best fit of the reparameterized Gompertz equation to the experimental data.

growth cycle compared with the control (Figure 3). Nonanoic acid is known to possess antimicrobial activity particularly on fungi and yeasts (Kiesel, 1913; Novak et al., 1969; Madhu et al., 2005). In the literature, no studies have been recorded on the effects of nonanoic acid on Pseudomonas spp. In fact, for these samples, the values of $\mathrm{MAL}_{\mathrm{P}}$ (Table 1 ) are always lower or similar to the traditional packaging. In an earlier work (Farbood et al., 1976), the antibacterial effect of rosemary extract in beef was examined on the growth of total bacterial count and on growth of Escherichia coli, Enterobacter aerogenes, Pseudomonas fluorescens, Salmonella typhimurium, and Staphylococcus aureus, and low bactericidal effects were observed. Lemon and orange also possess very little antimicrobial activity (Juven et al., 1994; Skandamis and Nychas, 2000; Suhr and Nielsen, 2003). To summarize, it is notable that essences such as lemon and sage from Alkott and lemon from Boyajian, at 3,000 and 6,000 $\mathrm{mg} / \mathrm{kg}$, were the most effective in prolonging the MAL of Pseudomonas spp.

\section{Coliforms}

Figures 4, 5, and 6 show the evolution of coliform count over a 6 - $d$ storage period. As in the previous paragraph, the tested compounds are divided into 3 groups depending on their antimicrobial effect. The control shows the following trend: a short lag phase, followed by a continued increase in the viable cell concentra- tion until the stationary phase. Conte et al. (2007a,b) also assessed the antimicrobial activity of citrus oil on total coliforms. The coliform count for lemon Boyajian at $3,000 \mathrm{mg} / \mathrm{kg}$ was significantly lower than the control during the observation period. Similar trends were observed for sweet orange, lemon (Boyajian at 3,000 and $6,000 \mathrm{mg} / \mathrm{kg}$, Primavera, and Alkott), sage, thymol, citral, and grapefruit seed extract (Figure 4).

Essential oils such as thyme, lemon (Aboca and Boyajian at $1,500 \mathrm{mg} / \mathrm{kg}$ ), and sour orange brought a slight decrease in coliform growth compared with the control (Figure 5), probably because of the protective effect of the food microorganisms (Hao et al., 1998).

Different behavior was recorded for lemon $20 \%$ (Spencer) at 5,000 and $10,000 \mathrm{mg} / \mathrm{kg}$, propolis, limonene, lemon (Agrumigel) at $5,000 \mathrm{mg} / \mathrm{kg}$, and lemon (Esperis) at 2,000 $\mathrm{mg} / \mathrm{kg}$ (Figure 6). In fact, the evolution of coliform count was slightly greater than the control during the storage period. It is remarkable that natural compounds such as lemon (Erbavita), nonanoic acid, rosemary, vanilla, and orange reached the MAL within 1 or $2 \mathrm{~d}$ (Figure 6). To the best of our knowledge, no study on the effects of rosemary, vanilla, and orange extract on coliforms is available in the literature.

The MAL values related to coliforms $\left(\mathbf{M A L}_{\mathbf{C}}\right)$ were determined according to what is reported above and listed in Table 1. As stated in DPR 54/97 (European Union, 1997), the value of $\log \left(N_{\max }\right)$ was set to 5 . In

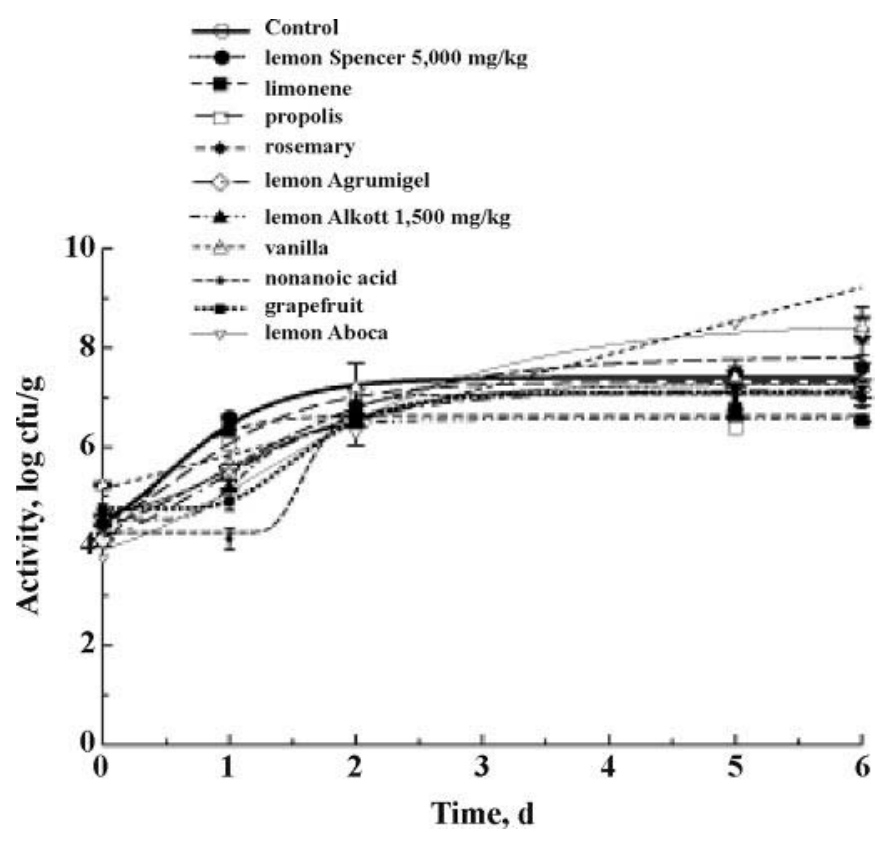

Figure 3. Antimicrobial activity of slowly effective compounds on Pseudomonas spp. count in Fior di latte cheese during storage at $10^{\circ} \mathrm{C}$. The curves shown in the figure are the best fit of the reparameterized Gompertz equation to the experimental data. 


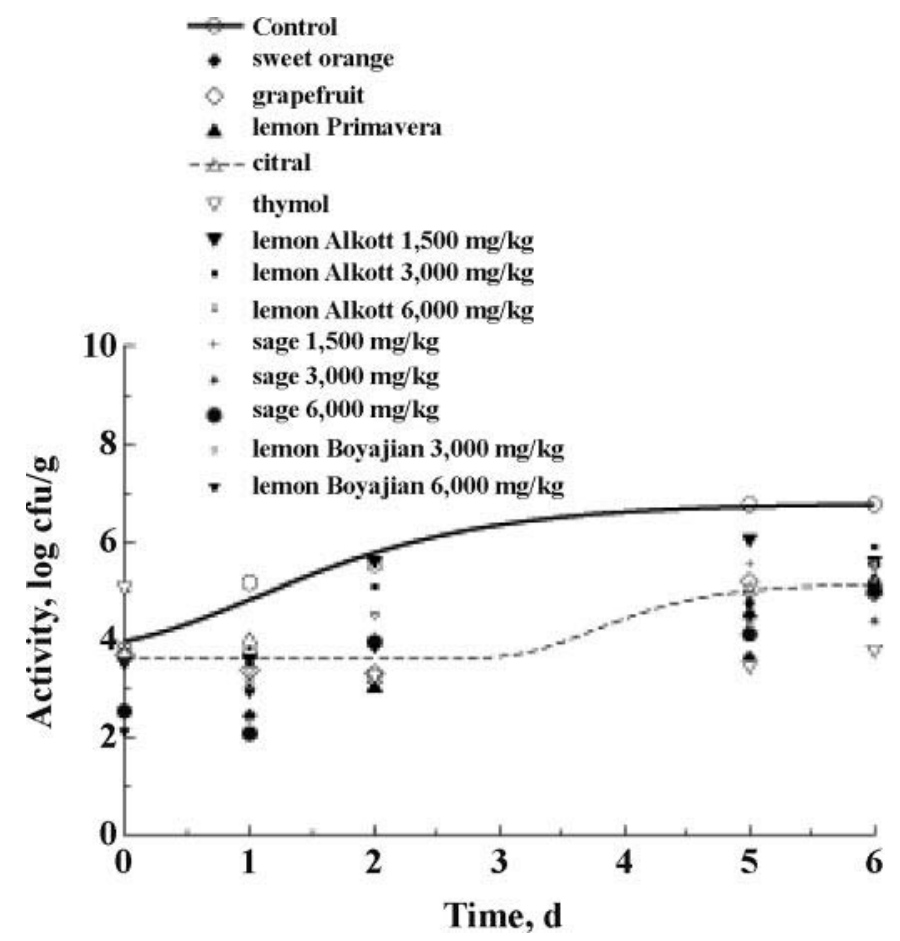

Figure 4. Antimicrobial activity of highly effective compounds on coliform count in Fior di latte cheese during storage at $10^{\circ} \mathrm{C}$. The curves shown in the figure are the best fit of the reparameterized Gompertz equation to the experimental data.

summary, sweet orange, sage, thymol, grapefruit, and lemon (Primavera, Alkott, and Boyajian) seemed to be the most effective compounds to prolong $\mathrm{MAL}_{\mathrm{C}}$ of coliforms in Fior di Latte cheese.

\section{MAL Values}

As also reported in the literature, when the microbial unacceptability of a given commodity is provoked by more than one microorganism, the MAL value of the packaged product is given by the lowest MAL among those calculated for each spoilage microorganism (i.e., MAL ${ }_{P}$ and $\mathrm{MAL}_{\mathrm{C}}$ ). In the third column of Table 1 , the MAL values of the packaged dairy products are listed. As can be seen, it was not possible to calculate the MAL value for vanilla, lemon (Erbavita), orange (Erbavita), nonanoic acid, and rosemary, because the viable cell concentration of coliforms was above its threshold limit at the beginning of storage. For a few natural compounds, such as lemon 20\% (Spencer) at 5,000 and $10,000 \mathrm{mg} / \mathrm{kg}$, propolis, lemon (Agrumigel) at $5,000 \mathrm{mg} / \mathrm{kg}$, lemon (Esperis) at $2,000 \mathrm{mg} / \mathrm{kg}$, and limonene, MAL values lower than the control were observed. Conversely, for thymol, grapefruit, sweet orange, lemon (Alkott) at $1,500 \mathrm{mg} / \mathrm{kg}$, lemon (Boyajian) at $6,000 \mathrm{mg} / \mathrm{kg}$, and lemon (Primavera) at $1,500 \mathrm{mg} /$ $\mathrm{kg}$, a MAL value slightly greater than the control was found. The MAL value was strongly affected by lemon and sage from Alkott and lemon from Boyajian. In fact, a MAL greater than $6 \mathrm{~d}$ was recorded.

\section{Lactic Acid Bacteria}

Figures 7 and 8 show the growth kinetics of rods and cocci lactic acid bacteria during storage, as determined at $37^{\circ} \mathrm{C}$ on MRS and M17 agar media, respectively. Because of the similar results obtained at all tested concentrations, only the experimental data of lemon (Boyajian), thymol, and vanilla were reported. As we can see, the functional microorganisms grew during refrigerated storage. Moreover, there were no marked differences between the control sample and those containing the active compounds. According to the literature, these results suggest that natural compounds do not affect the growth of lactic acid bacteria. Among the generally sensitive gram-positive bacteria, lactic acid bacteria are the most resistant to essential oils (Shelef, 1983; Blaszyk and Holley, 1998; Conte et al., 2007b). This microbial group was already present at high concentrations in the product immediately after packaging because of the technology used in dairy manufacture. The inefficiency of the tested natural oils on useful dairy bacteria is particularly important for a product such as Fior di Latte cheese, which is increasingly advertised as being "preservative-free and rich in viable lactic acid bacteria" (Coppola et al., 1995).

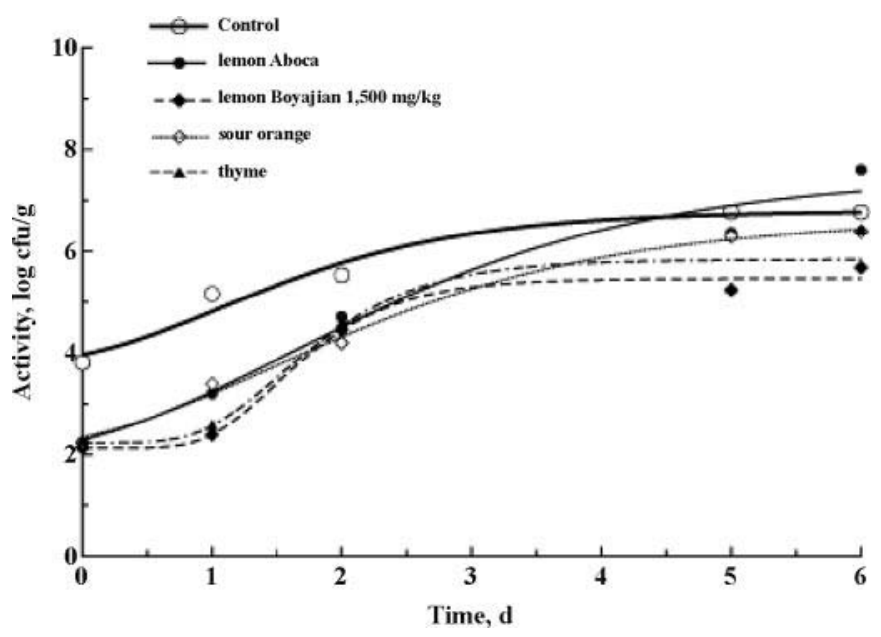

Figure 5. Antimicrobial activity of slowly effective compounds on coliform count in Fior di latte cheese during storage at $10^{\circ} \mathrm{C}$. The curves shown in the figure are the best fit of the reparameterized Gompertz equation to the experimental data. 


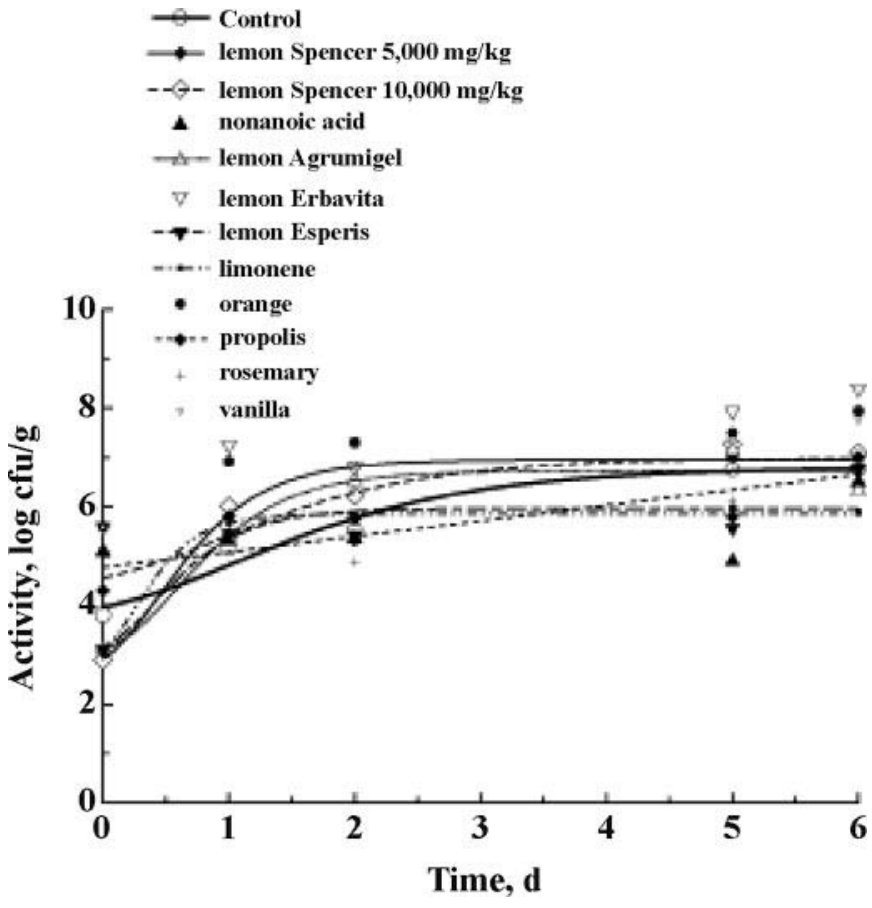

Figure 6. Antimicrobial activity of slowly effective compounds on coliform count in Fior di latte cheese during storage at $10^{\circ} \mathrm{C}$. The curves shown in the figure are the best fit of the reparameterized Gompertz equation to the experimental data.

\section{Yeasts and Mesophilic Total Count}

The amount of yeasts recorded during the storage period (data not shown), ranging from 2 to $5 \mathrm{log} \mathrm{cfu} / \mathrm{g}$, was in agreement with data reported in previous works (Nunez and Dias-Amado, 1981; Coppola et al., 1988). In fact, studies reported in the literature clearly show that yeasts are a significant part of the microflora, be-

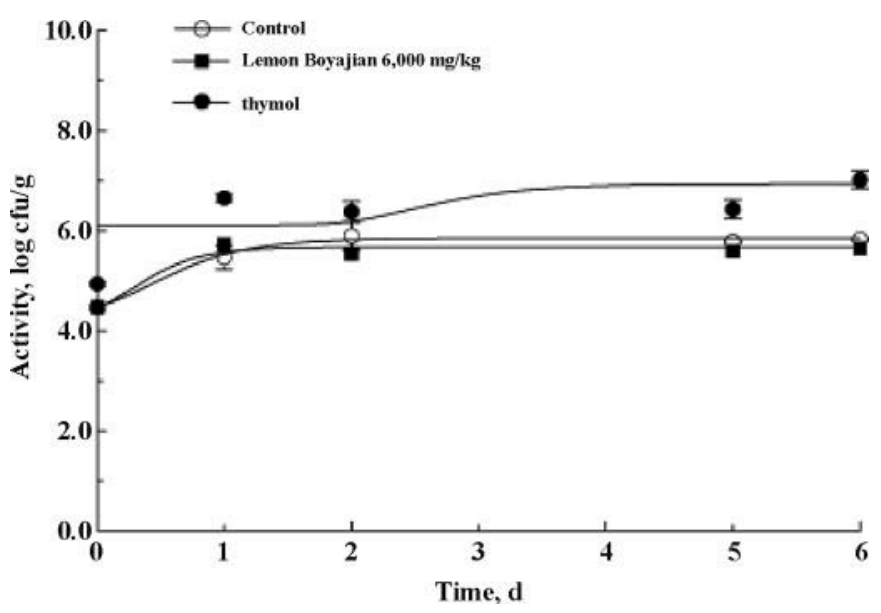

Figure 7. Evolution of lactic acid bacteria rod count in Fior di latte cheese during storage at $10^{\circ} \mathrm{C}$. The curves are the best fit of the Gompertz equation to the experimental data.

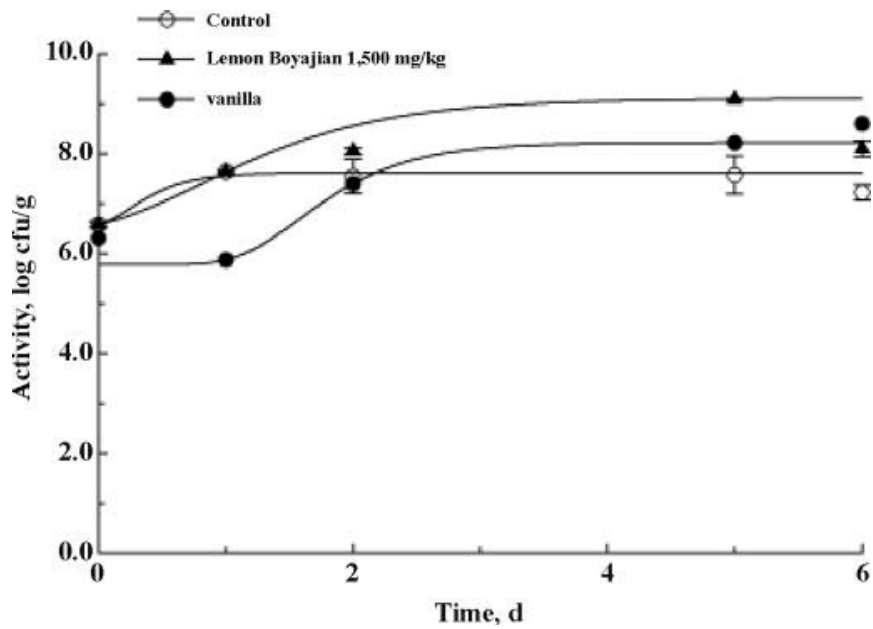

Figure 8. Evolution of lactic acid bacteria cocci count in Fior di latte cheese during storage at $10^{\circ} \mathrm{C}$. The curves are the best fit of the Gompertz equation to the experimental data.

ing responsible for the aromatic and sensorial characteristics of Mediterranean cheeses (Morea et al., 1999). The mesophilic total count was similar in all samples (data not shown).

\section{pH}

The $\mathrm{pH}$ of Fior di Latte cheese was monitored during the entire observation period (data not shown). Results show that it did not change much during storage (ranging between 5.80 and 5.40). Moreover, the $\mathrm{pH}$ values were not affected by the presence of active compounds, suggesting that the observed antimicrobial activity has to be exclusively ascribed to the effectiveness of the investigated natural compounds.

\section{CONCLUSIONS}

It can be concluded that the use of natural compounds such as lemon, sage, and thyme in Fior di Latte cheese inhibited the growth of microorganisms involved in spoilage. Therefore, a substantial prolongation of the microbial acceptability limit was obtained, without affecting useful microorganisms. It is also evident that not all essential oils act in the same manner. For this reason, in future studies, the use of a central composite design will be considered to assess the individual and interactive effects of some natural compounds on the microbial stability of this fresh dairy product. Moreover, Fior di Latte cheese quality sub-indices other than microbiological stability will be considered for a complete shelf-life evaluation. 


\section{ACKNOWLEDGMENTS}

This work was financially supported by Ministero dell'Economia e delle Finanze, Ministero dell'Istruzione, dell'Università e della Ricerca Scientifica e Tecnologica e l'Assessorato Bilancio e Programmazione Regione Puglia by the program "Accordo di Programma Quadro in Materia di Ricerca Scientifica della Regione Puglia - Progetto Strategico - Title: "Miglioramento della qualità dietetico-nutrizionale e sicurezza di produzioni casearie tradizionali della Capitanata."

\section{REFERENCES}

Bishop, J. R., and C. H. White. 1986. Assessment of dairy product quality and potential shelf life-A review. J. Food Prot. 49:739753.

Blaszyk, M., and R. A. Holley. 1998. Interaction of monolaurin, eugenol and sodium citrate on growth of common meat spoilage and pathogenic organisms. Int. J. Food Microbiol. 39:175-183.

Caccioni, D. R. L., M. Guizzardi, D. M. Biondi, A. Renda, and G. Ruberto. 1998. Relationships between volatile components of citrus fruit essential oils and antimicrobial action on Penicillium digitatum and Penicillium italicum. Int. J. Food Microbiol. 43:73-79.

Conte, A., C. Scrocco, M. Sinigaglia, and M. A. Del Nobile. 2007a. Innovative active packaging system to prolong the shelf life of Mozzarella cheese. J. Dairy Sci. 90:2126-2131.

Conte, A., M. Sinigaglia, and M. A. Del Nobile. 2007b. Use of lemon extract to inhibit the growth of malolactic bacteria. J. Food Prot. 70:114-118.

Coppola, R., E. Parente, S. Dumontet, and A. Peccerella. 1988. The microflora of natural whey cultures utilized as starters in the manufacture of Mozzarella cheese from water-buffalo milk. Lait 68:295-310.

Coppola, R., E. Sorrentino, L. Cinquanta, F. Rossi, M. Iorizzo, and L. Grazia. 1995. Shelf-life of Mozzarella cheese samples packaged without liquid and stored at different temperatures. Ital. J. Food Sci. 4:351-359.

Corbo, M. R., M. A. Del Nobile, and M. Sinigaglia. 2006. A novel approach for calculating shelf-life of minimally processed vegetables. Int. J. Food Microbiol. 106:69-73.

Deans, S. G., and G. Ritchie. 1987. Antibacterial properties of plant essential oils. Int. J. Food Microbiol. 5:165-180.

Delaquis, P. J., K. Stanich, B. Girad, and G. Mazza. 2002. Antimicrobial activity of individual and mixed fractions of dill, cilantro, coriander and eucalyptus essential oils. Int. J. Food Microbiol. 74:101-109.

Dorman, H. J. D., and S. G. Deans. 2000. Antimicrobial agents from plants: Antibacterial activity of plant volatile oils. J. Appl. Microbiol. 88:308-316.

European Union. 1997. DPR n. 54/97. Regolamento recante attuazione delle Dir. 92/46 e 92/47/CEE in materia di produzione e immissione sul mercato di latte e di prodotti a base di latte.

Farbood, M. I., J. H. Macneil, and K. Ostovar. 1976. Effect of rosemary spice extractive on growth of microorganisms in meats. J. Milk Food Technol. 39:675-679.

Gill, A. O., P. Delaquis, P. Russo, and R. A. Holley. 2002. Evaluation of antilisterial action of cilantro oil on vacuum packed ham. Int. J. Food Microbiol. 73:83-92.

Hao, Y. Y., R. E. Brackett, and M. P. Doyle. 1998. Inhibition of Listeria monocytogenes and Aeromonas hydrophila by plant extracts in refrigerated cooked beef. J. Food Prot. 61:307-312.

Holley, R. A., and D. Patel. 2005. Improvement in shelf life and safety of perishable food by plant essential oils and smoke antimicrobials. A review. Food Microbiol. 22:273-292.
Juven, B. J., J. Kanner, F. Schved, and H. Weisslowicz. 1994. Factors that interact with the antibacterial action of thyme essential oil and its active constituents. J. Bacteriol. 76:626-631.

Kiesel, A. 1913. The action of different acids and acid salts upon the development of Aspergillus niger. Ann. Inst. Pasteur (Paris) 27:391-420.

Kim, J., M. R. Marshall, and C. Wei. 1995. Antimicrobial activity of some essential oil components against five food pathogens. J. Agric. Food Chem. 43:2839-2845.

Lachowicz, K. J., G. P. Jones, D. R. Briggs, F. E. Bienvenu, J. Wan, A. Wilcock, and M. J. Coventry. 1998. The synergistic preservative effects of the essential oils of sweet basil (Ocimum basilicum L.) against acid-tolerant food microflora. Lett. Appl. Microbiol. 26:209-214.

Lanciotti, R., A. Gianotti, F. Patrignani, N. Belletti, M. E. Guerzoni, and F. Gardini. 2004. Use of natural aroma compounds to improve shelf-life and safety of minimally processed fruits. A Review. Trends Food Sci. Technol. 15:201-208.

Lis-Balchin, M., and S. G. Deans. 1997. Bioactivity of selected plant essential oils against Listeria monocytogenes. J. Appl. Microbiol. 82:759-762.

Madhu, A., T. J. Gianfagna, and P. K. Hebbar. 2005. Trichoderma harzianum produces nonanoic acid, an inhibitor of spore germination and mycelial growth of two cacao pathogens. Physiol. Mol. Plant Pathol. 67:304-307.

Mangena, T., and N. Y. O. Muyima. 1999. Comparative evaluation of the antimicrobial activities of essential oils of Artemisia afra, Pteronia incana and Rosmarinus officinalis on selected bacteria and yeast strains. Lett. Appl. Microbiol. 28:291-296.

Marino, M., C. Bersani, and G. Comi. 2001. Impedante measurement to study antimicrobial activity of essential oils from Lamiaceae and Compositae. Int. J. Food Microbiol. 67:187-195.

Mishra, A. K., and N. K. Dubey. 1994. Evaluation of some essential oils for their toxicity against fungi causing deterioration of stored food commodities. Appl. Environ. Microbiol. 60:1101-1105.

Morea, M., F. Baruzzi, and P. S. Cocconcelli. 1999. Molecular and physiological characterization of dominant populations in traditional Mozzarella cheese processing. J. Appl. Microbiol. 87:574-582.

Mucchetti, G., and E. Neviani. 2006. Microbiologia e tecnologia lattiero-casearia-Qualità e sicurezza. Tecniche Nuove, Milan, Italy.

Nakatani, N. 1994. Antioxidative and antimicrobial constituents of herbs and spice. Dev. Food Sci. 34:251-271.

Novak, A. F., J. M. Solar, R. R. Mod, F. C. Magne, and E. L. Skau. 1969. Antimicrobial activity of some N-substituted amides of long-chain fatty acids. Appl. Microbiol. 18:1050-1056.

Nunez, M. P. G. M., and C. Dias-Amado. 1981. Les levures et les moisissures dans le fromage bleu de Cabrales. Lait 61:62-79.

Parente, E., and G. Moschetti. 1997. Starters for mozzarella cheese. Pages $31-41$ in Proc. 5th Cheese Symp., Cork, Ireland. T. M. Cogan, P. F. Fox, and R. P. Ross, ed. Teagasc Publ., Dublin, Ireland.

Paster, N., B. J. Juven, E. Shaaya, M. Menasherov, R. Nitzan, H. Weisslowicz, and U. Ravid. 1990. Inhibitory effect of oregano and thyme essential oils on moulds and food-borne bacteria. Lett. Appl. Microbiol. 11:33-37.

Salvadori del Prato, O. 2001. Trattato di Tecnologia Casearia. Agricole, Bologna, Italy.

Shelef, L. A. 1983. Antimicrobial effects of spices. J. Food Saf. 6:2944.

Skandamis, P. N., and G. J. E. Nychas. 2000. Development and evaluation of a model predicting the survival of Escherichia coli O157:H7 NCTC 12900 in homemade eggplant salad at various temperatures, $\mathrm{pHs}$ and oregano essential oil concentrations. Appl. Environ. Microbiol. 66:1646-1653.

Skandamis, P. N., E. Tsigarida, and G. J. E. Nychas. 2002. The effect of oregano essential oil on survival/death of Salmonella typhimurium in meat stored at $5^{\circ} \mathrm{C}$ under aerobic, VP/MAP condition. Food Microbiol. 19:97-103. 
Smid, E. J., and L. G. M. Gorris. 1999. Natural antimicrobials for food preservation. Pages 285-308 in Handbook of Food Preservation. M. S. Rahman, ed. Marcel Dekker, New York, NY.

Smith-Palmer, A., J. Stewart, and L. Fyfe. 1998. Antimicrobial properties of plant essential oils and essences against five important food-borne pathogens. Lett. Appl. Microbiol. 26:118122

Smith-Palmer, A., J. Stewart, and L. Fyfe. 2001. The potential application of plant essential oils as natural food preservatives in soft cheese. Food Microbiol. 18:463-470.

Spano, G., E. Goffredo, L. Beneduce, D. Tarantino, A. Dupuy, and S. Massa. 2003. Fate of Escherichia coli O157:H7 during the manufacture of Mozzarella cheese. Lett. Appl. Microbiol. 36:7376.
Suhr, K. I., and P. V. Nielsen. 2003. Antifungal activity of essential oils evaluated by two different application techniques against rye bread spoilage fungi. J. Appl. Microbiol. 94:665-674.

Tassou, C. C., E. H. Drosinos, and G. J. E. Nychas. 1996. Inhibition of resident microbial flora and pathogen inocula on cold fresh fish fillets in olive oil, oregano and lemon juice under modified atmosphere or air. J. Food Prot. 59:31-34.

Tassou, C., K. Koutsoumanis, and G. J. E. Nychas. 2000. Inhibition of Salmonella enteritidis and Staphylococcus aureus in nutrient broth by mint essential oil. Food Res. 33:273-280.

Vrinda Menon, K., and S. R. Garg. 2001. Inhibitory effect of clove oil on Listeria monocytogenes in meat and cheese. Food Microbiol. 18:647-650. 